\title{
Development of multiparameter equations for satellite monitoring analysis of traffic flow
}

\author{
Alexander Testeshev ${ }^{1}$, VeraTimohovetz ${ }^{1, *}$, and Tatyana Mikeladze ${ }^{1}$ \\ ${ }^{1}$ Tyumen Industrial University, 625000 Tyumen, Russia
}

\begin{abstract}
The paper is dedicated to the development of multiparameter equations of traffic flows for satellite monitoring analysis of the road networks of major cities. Use of multiparameter dependences will allow interpreting the road situation by transforming a static image into dynamic characteristics of traffic and refuse from multiple mono-dependences which account road and weather conditions. Multiparameter dependences are developed based on mathematical methods for traffic flow modeling. The issue of using cartographic resources with updatable databases are investigated, sufficient amount of observation samples was determined for development of reliable functional dependences. The suggested method allows minimizing resource expenses on creation of calculation framework for analysis of network monitoring results for traffic flows on road networks of modern metropolises.
\end{abstract}

\section{Introduction}

Multifunctionality of urban territories and abundance of routes are the main factors that make selective control of traffic flow in modern metropolises ineffective for obtaining the full vision of traffic situation. Subject of the research is development of method for network monitoring of roads in major cities.

Representative data on traffic flows characteristics are required for making managerial decisions on urban infrastructure development. It is difficult to obtain such data using the known methods due to high labor intensity and economic costs.

Remote monitoring method based on analysis of satellite images from open sources is one of the most promising directions of network research [1]. Functional dependences of traffic flow theory serve for decoding and recognition of dynamic parameters of the flow (traffic intensity and speed) using a static image (flow density) [2-5]. Review of the topical research [6-8] showed incomplete correspondence of the existing deterministic model with the modern requirements to mathematical methods of traffic modeling.

This research is aimed at improving mathematical tools for decoding satellite data with the purpose to solve operational tasks of transport infrastructure management.

*Corresponding author: verochka1987@mail.ru 


\section{Calculation methods}

One of the most labor-intensive and important stages of the studied method is development of mathematical dependences of traffic flow which account traffic $\left(T_{i}\right)$, $\operatorname{road}\left(M_{j}\right)$ and weather conditions $\left(R_{k}\right)$ [9].

The need in account of these variable factors consists in the necessity to develop a set of monodependences which accumulate a set of certain conditions for each scenario (Fig. 1).

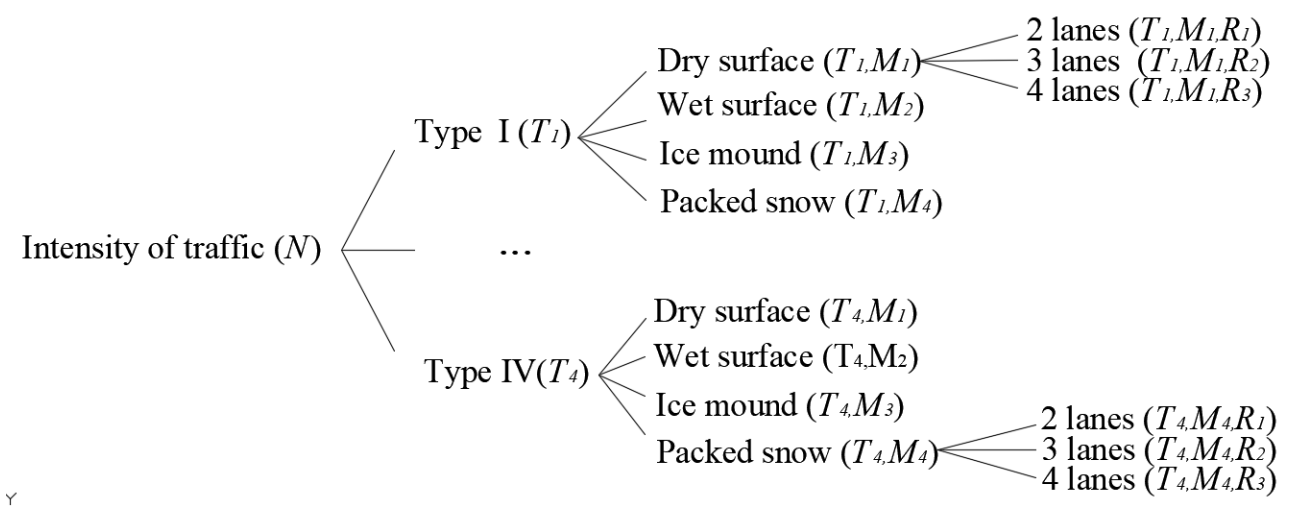

Fig. 1. Structural scheme of rows of variable factors for different monodependences.

Systematic study of traffic in mesoscale of 4 major cities of a single Federal district of the Russian Federation (RF) requires development of at least 64 monodependences [1], which considerably complicates the use of mathematical tool for satellite image decoding.

Analysis in macroscale of the territory of the country requires essentially different concept for equation development. It shall have open architecture and allow defining the unknown parameters through correction factors of variable conditions for universal dependences with regard to the reference conditions.

This criterion defines the necessity of transition to mathematical model represented by graphical dependence of the type $N=f\left(\rho_{i j n}\right)$ [2] to the following multiparameter function that includes quantitative account of the variable factors:

$$
N(\rho)=f\left(\rho, S_{T}^{M}, P_{T, R}^{M}\right),
$$

where $S_{T}^{M}$ - reduction factor of actual road surface condition $\left(M_{j}\right)$, type of street $\left(T_{i}\right)$ to the reference road surface $\left(M_{1}\right)$;

$P_{T, R}^{M}$ - reduction factor of design number of same-direction lanes $\left(R_{j}\right)$, road surface $\left(M_{j}\right)$, type of street $\left(T_{i}\right)$ to the reference number of lanes $\left(R_{l}\right)$.

Among the advantages of the suggested method is the ability to adjust correction factors with the account of variable conditions without variation of the basic dependence. In prospective development of urban territories, this allows extending the nomenclature of design conditions of the road surface and variability of lane number, as well as improving precision of calculations due to increase in the volume of statistical sampling. Besides, analogously with [10], in case of the need to detect traffic in non-reference period, the suggested algorithm will enable to indirectly define the traffic flow parameters due to correction factors.

Development of dependences according to the suggested method required to account regional peculiarities of the major cities of the RF, such as Moscow, Saint Petersburg, 
Novosibirsk, Yekaterinburg, Nizhniy Novgorod, Rostov-on-Don, Irkutsk, Kemerovo, Krasnoyarsk, Lipetsk, Omsk, Ryazan, Saratov, Tolyatti and Yaroslavl.

The above-mentioned peculiarities include search of constantly updated electronic sources of satellite images, justification of sufficient amount of observation samples, beginning of citizens' daily activity in each city.

One of the main advantages of the method is the ability to use free and regularly updated content [11], for this purpose cartographic services were carefully selected.

During this selection process frequency and dates of the database updates were determined (Table 1).

Table 1. Frequency of updates of free Russian language online sources in the RF territory for the last 5 years.

\begin{tabular}{|c|c|c|c|c|c|c|}
\hline Year & $\begin{array}{c}\text { Bing } \\
\text { Maps }\end{array}$ & $\begin{array}{c}\text { Yahoo! } \\
\text { Maps }\end{array}$ & $\begin{array}{c}\text { Yandex.M } \\
\text { aps }\end{array}$ & Google Maps & $\begin{array}{c}\text { Rambler- } \\
\text { Maps }\end{array}$ & $\begin{array}{c}\text { Maps } \\
\text { Mail.Ru }\end{array}$ \\
\hline 2012 & - & - & - & $20.10 ; 17.12$. & - & - \\
\hline 2013 & - & - & - & - & - & $\begin{array}{c}\text { Terminated its } \\
\text { operation }\end{array}$ \\
\hline 2014 & - & 6.10. & - & $\begin{array}{c}07.03 ; 29.09 ; \\
06.10 .\end{array}$ & $\begin{array}{c}\text { Terminated } \\
\text { its operation }\end{array}$ & - \\
\hline 2015 & - & - & - & $03.06 ; 06.08$. & - & - \\
\hline 2016 & - & - & 15.04. & $08.11 ; 24.11$. & - & - \\
\hline 2017 & - & - & - & 01.05. & - & - \\
\hline
\end{tabular}

Additionally, foreign paid cartographic services were analyzed: TomTom (the Netherlands), HEREmaps (Germany), Paikkatietoikkuna (Finland), Applemaps (USA), geo.admin.ch (Switzerland), Allgemeng - Geoportal Luxembourg (Luxemburg) and Gisserver.nic.in (India), the last one has limited access. Comparative analysis proved Googlemaps to be the most appropriate website with the most relevant and update information.

Necessary condition for development of objective and accurate decoding algorithm was sufficient amount of observation samples within the research [6].

Amount of observation samples (n) was calculated based on mean traffic intensity $(\overline{\mathrm{N}})$; average values of relative accuracy of records $(\Delta)$ and relative probability function $(\operatorname{ta})$ are confirmed for all metropolises. Then, root mean square error for a certain value of intensity was found with regard to average value $(\sigma)$ and variation coefficient $(v)$. In order to verify validity of the obtained data, absolute error $(\xi)$ was defined, the value of which lies within the specification range (Table 2).

Table 2. Fragment of the table for minimum amount of measurements.

\begin{tabular}{|c|c|c|c|c|c|c|c|}
\hline Cities & $\Delta$ & $\xi$ & $\sigma$ & $v$ & $t_{\alpha}$ & $\overline{\mathrm{N}}$ & $n$ \\
\hline Moscow & 0.11 & 10865.9 & 33585.5 & 0.264 & 1.65 & 98781 & 16 \\
\hline $\begin{array}{c}\text { Saint } \\
\text { Petersburg }\end{array}$ & 0.11 & 4842.97 & 14528.91 & 0.256 & 1.65 & 44027 & 15 \\
\hline Novosibirsk & 0.11 & 9113.94 & 26513.28 & 0.249 & 1.65 & 82854 & 14 \\
\hline
\end{tabular}

While specifying typology of roads and streets of the metropolises under study the beginning of the life cycle of the city was accounted. Thus, for types I and II various temporary transport demand was observed, due to this fact division of the RF territory on time zones was accounted while remote monitoring, in the part of displacement of traffic investigation intervals for various cities (Table 3). 
Table 3. Fragment of table for displacement of intensity peak values for various cities.

\begin{tabular}{|c|c|c|c|c|c|c|c|}
\hline \multirow{3}{*}{$\stackrel{己}{己}$} & \multirow{3}{*}{ 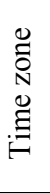 } & \multicolumn{6}{|c|}{ Type of roads and streets } \\
\hline & & \multicolumn{3}{|c|}{ I } & \multicolumn{3}{|c|}{ II } \\
\hline & & Street & $\begin{array}{l}\text { Charact- } \\
\text { eristics }\end{array}$ & $\begin{array}{c}\text { Peak } \\
\text { hours, } \\
\text { h }\end{array}$ & Street & $\begin{array}{c}\text { Charact- } \\
\text { eristics }\end{array}$ & $\begin{array}{c}\text { Peak } \\
\text { hours, } \\
\mathrm{h}\end{array}$ \\
\hline \multirow{3}{*}{$\begin{array}{l}3 \\
0 \\
0 \\
0 \\
0^{3}\end{array}$} & \multirow{3}{*}{$\sum_{0}^{m}$} & Volgogradsky Ave. & Periphery & \multirow{3}{*}{$\begin{array}{c}6: 00- \\
8: 00 \\
15: 00- \\
19: 00\end{array}$} & Eniseyskaya & Periphery & $\begin{array}{l}6: 00- \\
10 \cdot 00\end{array}$ \\
\hline & & Yunykh Lenintsev & Periphery & & Nizhegorodskaya & Periphery & $\begin{array}{l}11: 00- \\
14 \cdot 00\end{array}$ \\
\hline & & $\begin{array}{l}\text { Akademika } \\
\text { Skryabina }\end{array}$ & Periphery & & Skobelevskaya & Periphery & $\begin{array}{l}19: 00- \\
21: 00\end{array}$ \\
\hline \multirow{3}{*}{ 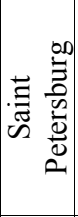 } & \multirow{3}{*}{$\sum_{j}^{\infty}$} & Nevsky Ave. & Center & \multirow{3}{*}{$\begin{array}{c}8: 00- \\
11: 00 \\
18: 00- \\
20: 00\end{array}$} & Liteynyi Ave. & Center & $\begin{array}{l}8: 00- \\
11: 00\end{array}$ \\
\hline & & Glavnaya & Periphery & & Sadovaya & Center & $\begin{array}{l}11: 00- \\
14: 00\end{array}$ \\
\hline & & Stolyarny Lane & Center & & Zarechnaya & Periphery & $\begin{array}{l}19: 00- \\
21: 00\end{array}$ \\
\hline \multirow{3}{*}{ 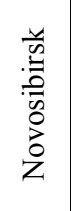 } & \multirow{3}{*}{$\sum_{0}^{+}$} & Planovaya & Periphery & \multirow{3}{*}{$\begin{array}{c}6: 00- \\
10: 00 \\
17: 00- \\
20: 00\end{array}$} & Lenina Sa & Center & $6: 00-$ \\
\hline & & Kirova & Center & & Oktyabrskaya & Center & 12:00- \\
\hline & & Mostovaya & Center & & Dimitrova Ave. & Center & $\begin{array}{l}16: 00- \\
19: 00\end{array}$ \\
\hline
\end{tabular}

Remote monitoring of sufficient amount of observation samples was performed for major RF cities with the account of defined peculiarities, which allowed presenting a set of statistical observations through graphical dependences (Fig. 2) for various traffic, road and weather conditions.

a)

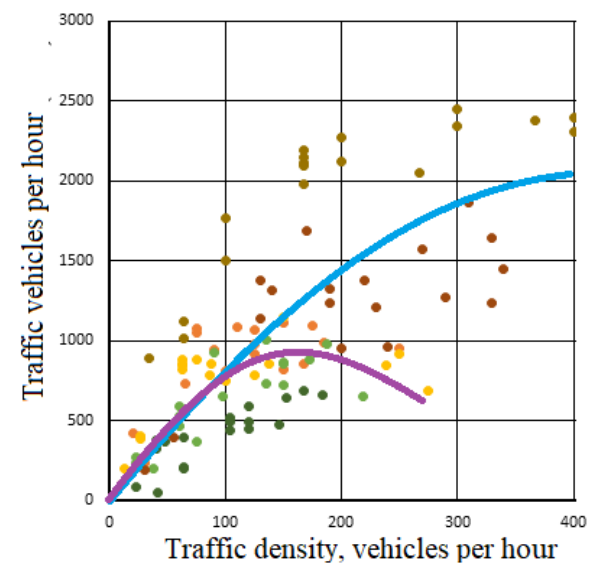

b)

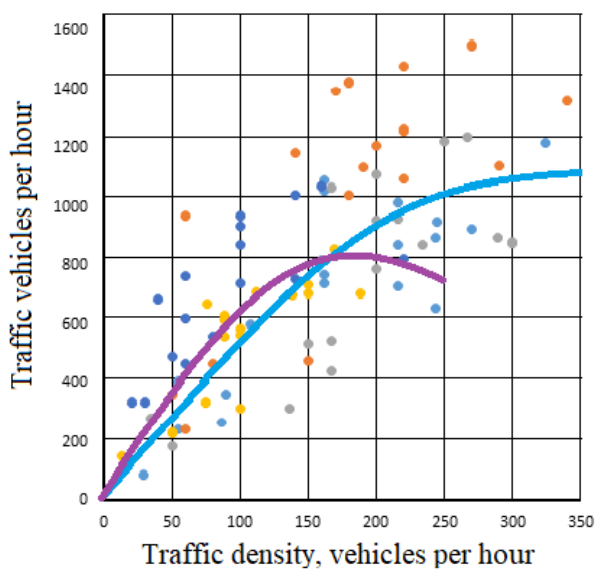


c)

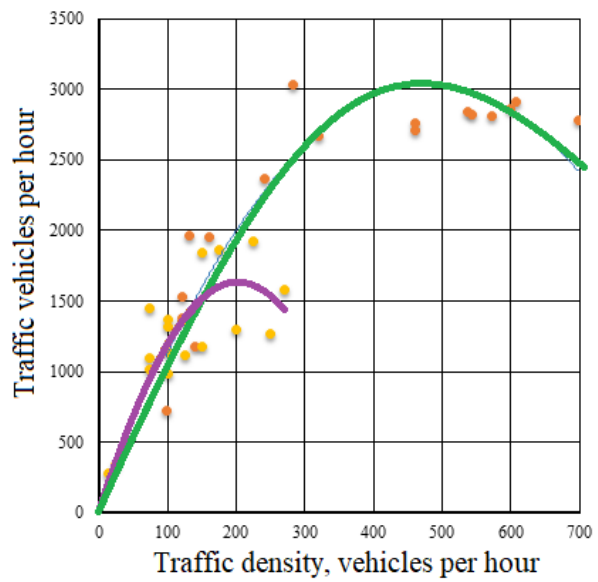

d)

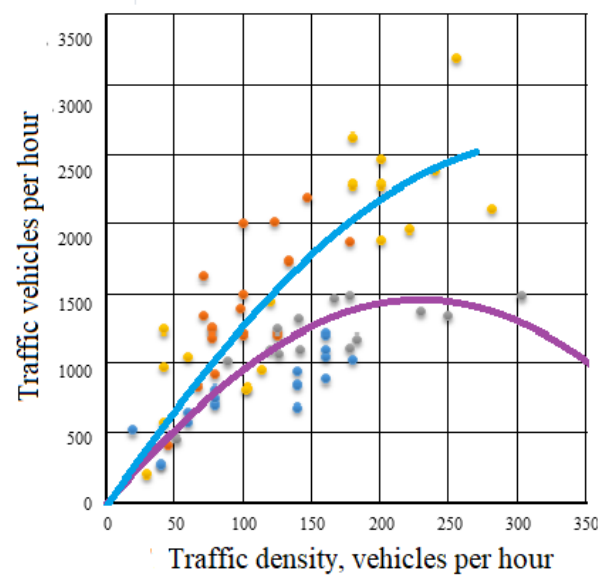

Conventional notation:

-2 traffic lane -3 traffic lane -4 traffic lane

Fig. 2 Examples of dependences of traffic intensity on traffic flow density for various cities and streets with different number of lanes and for dry surface: a) 1 type; b) 2 type; c) 3 type; d) 4 type.

Due to similar behavior of graphical dependences for each type basic multiparametric equations were developed with regard to reference conditions, which can then be reduced to the design conditions by using correction coefficients.

According to the method described in [12], the reference conditions are represented by a single vehicle movement on a dry surface along straight horizontal road; for rough surface the adhesion coefficient in wet state is no lower than 0.6; evenness is no higher than 3.0 $\mathrm{m} / \mathrm{km}$; coefficient of rolling resistance is $0.01-0.02$.

Cumulative account of the above factors is represented by a system of coefficients for variable parameters which are put in the basic equation. The system of coefficients and the basic equation were defined using methods of mathematical treatment and statistics.

Common structure of basic multiparametric equations is presented as follows:

a) for type I: $N(\rho)=\frac{-0,0289 \cdot\left(S_{T}^{M} \cdot P_{T, R}^{M} \cdot \rho\right)^{2}+9,6731 \cdot S_{T}^{M} \cdot P_{T, R}^{M} \cdot \rho}{s_{T}^{M} \cdot p_{T, R}^{M}}$

b) for type II: $N(\rho)=\frac{-0,0285 \cdot\left(s_{T}^{M} \cdot P_{T, R}^{M} \cdot \rho\right)^{2}+13,316 \cdot S_{T}^{M} \cdot P_{T, R}^{M} \rho}{s_{T}^{M} \cdot p_{T, R}^{M}}$

c) for type III: $N(\rho)=\frac{-0,0415 \cdot\left(S_{T}^{M} \cdot P_{T, R}^{M} \cdot \rho\right)^{2}+16,494 \cdot S_{T}^{M} \cdot P_{T, R}^{M} \cdot \rho}{s_{T}^{M} * p_{T R}^{M}}$

d) for type IV: $N(\rho)=\frac{-0,03 \text { ë38 } \cdot\left(S_{T}^{M} \cdot P_{T, R}^{M} \cdot \rho\right)^{2}+11,457 \cdot S_{T}^{M} \cdot P_{T, R}^{M} \cdot \rho}{s_{T}^{M} \cdot p_{T, R}^{M}}$ 


\section{Results}

Based on the results of iterative calculations reduction factors for actual monitoring conditions were developed for each type of basic equation (formulae 2-5).

The obtained coefficients of street lane pattern and urban roads account for various cities are given in the Table 4 .

Table 4. Reduction factors for lane number.

\begin{tabular}{|c|c|c|c|c|c|}
\hline \multirow{2}{*}{$\begin{array}{c}\text { Typ } \\
\text { e }\end{array}$} & \multirow[b]{2}{*}{ Lanes } & \multicolumn{4}{|c|}{ Surface condition } \\
\hline & & $\begin{array}{c}\text { Dry, } \\
M_{I} \\
\end{array}$ & $\begin{array}{c}\text { Wet, } \\
M_{2}\end{array}$ & $\begin{array}{c}\text { Ice mound, } \\
M_{3} \\
\end{array}$ & $\begin{array}{c}\text { Packed snow, } \\
M_{4} \\
\end{array}$ \\
\hline \multirow{6}{*}{$T_{1}$} & \multirow{2}{*}{$2, n_{l}$} & $P_{1,1}^{1}=1,0000$ & $P_{1,1}^{2}=1,0000$ & $P_{1,1}^{3}=1,0000$ & $P_{1,1}^{4}=1,0000$ \\
\hline & & $\overline{p_{1,1}^{1}=1,0000}$ & $\overline{p_{1,1}^{2}=1,0000}$ & $\overline{p_{1,1}^{3}=1,0000}$ & $\overline{p_{1,1}^{4}=1,0000}$ \\
\hline & \multirow{2}{*}{$3, n_{2}$} & $P_{1,2}^{1}=0,7346$ & $P_{1,2}^{2}=1,1218$ & $P_{1,2}^{3}=0,3036$ & $P_{1,2}^{4}=0,5234$ \\
\hline & & $\overline{p_{1,2}^{1}=0,6963}$ & $\overline{p_{1,2}^{2}=0,8140}$ & $\overline{p_{1,2}^{3}=0,2756}$ & $\overline{p_{1,2}^{4}=0,5110}$ \\
\hline & \multirow{2}{*}{$4, n_{3}$} & $P_{1,3}^{1}=0,3746$ & $P_{1,3}^{2}=0,2974$ & $P_{1,3}^{3}=3,1766$ & $P_{1,3}^{4}=0,4299$ \\
\hline & & $p_{1,3}^{1}=0,3686$ & $\overline{p_{1,3}^{2}}=0,3461$ & $\overline{p_{1,3}^{3}=3,3636}$ & $p_{1,3}^{4}=0,5221$ \\
\hline \multirow{6}{*}{$T_{2}$} & \multirow{2}{*}{$2, n_{l}$} & $P_{2,1}^{1}=1,0000$ & $P_{2,1}^{2}=1,0000$ & $P_{2,1}^{3}=1,0000$ & $P_{2,1}^{4}=1,0000$ \\
\hline & & $\overline{p_{2,1}^{1}=1,0000}$ & $\overline{p_{2,1}^{2}=1,0000}$ & $\overline{p_{2,1}^{3}=1,0000}$ & $\overline{p_{2,1}^{4}=1,0000}$ \\
\hline & \multirow[b]{2}{*}{$3, n_{2}$} & $P_{2,2}^{1}=1,6333$ & $P_{2,2}^{2}=0,7798$ & $P_{2,2}^{3}=0,3059$ & $P_{2,2}^{4}=0,4194$ \\
\hline & & $\overline{p_{2,2}^{1}=1,8065}$ & $p_{2,2}^{2}=0,3389$ & $p_{2,2}^{3}=0,2168$ & $p_{2,2}^{4}=0,6174$ \\
\hline & \multirow{2}{*}{$4, n_{3}$} & $P_{2,3}^{1}=0,4686$ & $P_{2,3}^{2}=0,4149$ & $P_{2,3}^{3}=0,3787$ & $P_{2,3}^{4}=0,4929$ \\
\hline & & $\overline{p_{2,3}^{1}=0,5129}$ & $\overline{p_{2,3}^{2}}=0,6519$ & $\overline{p_{2,3}^{3}=0,3140}$ & $\overline{p_{2,3}^{4}=1,4737}$ \\
\hline \multirow{6}{*}{$T_{3}$} & \multirow{2}{*}{$2, n_{l}$} & $P_{3,1}^{1}=1,0000$ & $P_{3,1}^{2}=1,0000$ & $P_{3,1}^{3}=1,0000$ & $P_{3,1}^{4}=1,0000$ \\
\hline & & $\overline{p_{3,1}^{1}=1,0000}$ & $\overline{p_{3,1}^{2}=1,0000}$ & $\overline{p_{3,1}^{3}=1,0000}$ & $p_{3,1}^{4}=1,0000$ \\
\hline & \multirow{2}{*}{$3, n_{2}$} & $P_{3,2}^{1}=0,4771$ & $P_{3,2}^{2}=0,5510$ & $P_{3,2}^{3}=0,5665$ & $P_{3,2}^{4}=0,3633$ \\
\hline & & $\overline{p_{3,2}^{1}=1,3121}$ & $\overline{p_{3,2}^{2}}=0,1732$ & $\overline{p_{3,2}^{3}=0,2478}$ & $\overline{p_{3,2}^{4}=0,3637}$ \\
\hline & \multirow{2}{*}{$4, n_{3}$} & $P_{3,3}^{1}=0,4241$ & $P_{3,3}^{2}=0,3001$ & $P_{3,3}^{3}=0,5591$ & $P_{3,3}^{4}=0,4056$ \\
\hline & & $\overline{p_{3,3}^{1}=0,5610}$ & $\overline{p_{3,3}^{2}=0,3601}$ & $\overline{p_{3,3}^{3}}=0,3035$ & $\overline{p_{3,3}^{4}=0,7835}$ \\
\hline \multirow{6}{*}{$T_{4}$} & \multirow{2}{*}{$2, n_{l}$} & $P_{4,1}^{1}=1,0000$ & $P_{4,1}^{2}=1,0000$ & $P_{4,1}^{3}=1,0000$ & $P_{4,1}^{4}=1,0000$ \\
\hline & & $\overline{p_{4,1}^{1}=1,0000}$ & $\overline{p_{4,1}^{2}}=1,0000$ & $\overline{p_{4,1}^{3}=1,0000}$ & $p_{4,1}^{4}=1,0000$ \\
\hline & \multirow{2}{*}{$3, n_{2}$} & $P_{4,2}^{1}=0,3402$ & $P_{4,2}^{2}=1,2609$ & $P_{4,2}^{3}=0,2941$ & $P_{4,2}^{4}=0,2615$ \\
\hline & & $\overline{p_{4,2}^{1}=0,2122}$ & $\overline{p_{4,2}^{2}=0,8856}$ & $\overline{P_{4,3}^{3}=0,1834}$ & $\overline{P_{4,2}^{4}=0,1862}$ \\
\hline & \multirow{2}{*}{$4, n_{3}$} & $P_{4,3}^{1}=0,4026$ & $P_{4,3}^{2}=0,3421$ & $P_{4,3}^{3}=0,3719$ & $P_{4,3}^{4}=0,1819$ \\
\hline & & $\overline{p_{4,3}^{1}=0,2838}$ & $\overline{p_{4,3}^{2}=0,4060}$ & $\overline{P_{4,3}^{3}=0,3221}$ & $\overline{P_{4,3}^{4}=0,1408}$ \\
\hline
\end{tabular}

Note: * above fraction - value of the factor put in the numerator of the basic equation; below fraction - value of the factor put in the denominator of the basic equation.

The developed reduction factors for surface condition to the type of street are presented in Table 5 .

Table 5. Reduction factors for surface conditions.

\begin{tabular}{|c|c|c|c|c|}
\hline \multirow{2}{*}{ Type } & \multicolumn{4}{|c|}{ Surface condition } \\
\cline { 2 - 5 } & $\begin{array}{c}\text { Dry, } \\
M_{1}\end{array}$ & $\begin{array}{c}\text { Wet, } \\
M_{2}\end{array}$ & $\begin{array}{c}\text { Ice mound, } \\
M_{3}\end{array}$ & Packed snow, $M_{4}$ \\
\hline \multirow{2}{*}{$T_{1}$} & $\frac{S_{1}^{1}=1,0000}{S_{1}^{1}=1,0000}$ & $\frac{S_{1}^{2}=1,2338}{S_{1}^{2}=0,7061}$ & $\frac{S_{1}^{3}=1,7627}{S_{1}^{3}=0,834}$ & $\frac{S_{1}^{4}=1,3609}{s_{1}^{4}=0,6915}$ \\
\hline \multirow{2}{*}{$T_{2}$} & $\frac{S_{2}^{1}=1,0000}{S_{2}^{1}=1,0000}$ & $\frac{S_{2}^{2}=1,1005}{S_{2}^{2}=0,8850}$ & $\frac{S_{2}^{3}=2,1564}{S_{2}^{3}=2,2089}$ & $\frac{S_{2}^{4}=2,0239}{S_{2}^{4}=0,9163}$ \\
\hline
\end{tabular}




\begin{tabular}{|c|c|c|c|c|}
\hline$T_{3}$ & $\frac{S_{3}^{1}=1,0000}{S_{3}^{1}=1,0000}$ & $\frac{S_{3}^{3}=1,3248}{S_{4}^{3}=1,8210}$ & $\frac{S_{3}^{3}=0,3093}{S_{4}^{3}=0,4671}$ & $\frac{S_{3}^{3}=2,0918}{S_{3}^{3}=1,8159}$ \\
\hline$T_{4}$ & $\frac{S_{4}^{1}=1,0000}{S_{4}^{1}=1,0000}$ & $\frac{S_{3}^{2}=0,9909}{S_{3}^{2}=0,9564}$ & $\frac{S_{4}^{3}=1,5928}{S_{4}^{3}=1,3441}$ & $\frac{S_{4}^{4}=2,9980}{S_{4}^{4}=2,4740}$ \\
\hline
\end{tabular}

Validity of the obtained values when compared to the actual traffic intensity was assessed using mean squared error (Table 6).

Table 6. Fragment of values for deviation of actual intensity from design intensity.

\begin{tabular}{|c|c|c|c|c|c|c|c|}
\hline & & \multicolumn{3}{|c|}{ Variable factors } & \multicolumn{3}{c|}{ Deviations } \\
\cline { 3 - 8 } No. & Legend & Type & $\begin{array}{c}\text { Surface } \\
\text { condition }\end{array}$ & $\begin{array}{c}\text { Number } \\
\text { of lanes }\end{array}$ & $\begin{array}{c}\text { between } \\
\text { design and } \\
\text { actual } \sigma, \%\end{array}$ & $\begin{array}{c}\text { Mean error of } \\
\text { approximation } \\
\overline{\mathrm{A}}, \%\end{array}$ & $\begin{array}{c}\text { Coefficient } \\
\text { of variation } \\
c_{N}, \%\end{array}$ \\
\hline 1 & $T_{4} M_{1} R_{1}$ & 4 & Dry & 2 & 9.17 & 21.62 & 31.47 \\
\hline 2 & $T_{4} M_{1} R_{2}$ & 4 & Dry & 3 & 5.95 & 18.24 & 33.69 \\
\hline 3 & $T_{4} M_{1} R_{3}$ & 4 & Dry & 4 & 6.25 & 12.10 & 32.96 \\
\hline 4 & $T_{4} M_{2} R_{1}$ & 4 & Wet & 2 & 7.44 & 18.23 & 20.24 \\
\hline 5 & $T_{4} M_{2} R_{2}$ & 4 & Wet & 3 & 8.18 & 10.18 & 16.79 \\
\hline 6 & $T_{4} M_{2} R_{3}$ & 4 & Wet & 4 & 10.92 & 22.24 & 33.17 \\
\hline 7 & $T_{4} M_{3} R_{1}$ & 4 & Ice mound & 2 & 12.50 & 24.12 & 30.85 \\
\hline 8 & $T_{4} M_{3} R_{2}$ & 4 & Ice mound & 3 & 14.28 & 20.16 & 22.76 \\
\hline 9 & $T_{4} M_{3} R_{3}$ & 4 & Ice mound & 4 & 4.62 & 17.89 & 30.47 \\
\hline 10 & $T_{4} M_{4} R_{1}$ & 4 & Packed snow & 2 & 3.72 & 26.36 & 20.40 \\
\hline 11 & $T_{4} M_{4} R_{2}$ & 4 & Packed snow & 3 & 11.00 & 21.26 & 30.11 \\
\hline 12 & $T_{4} M_{4} R_{3}$ & 4 & Packed snow & 4 & 11.24 & 7.89 & 28.96 \\
\hline
\end{tabular}

\section{Conclusion}

The assessment results showed that the the deviation of actual values from the design ones for each condition lies within the range from 3 to $14 \%$, which characterizes representation of the obtained data while solving spatial problems.

These positive results of the suggested methodology serve as a basis for verification of mathematical tools universality for the world metropolises scale. Further improvement of the methodology is possible through extension of geography of the studied objects and use of paid content. Increase in resolving power of satellite images enables to verify differentiation of the studied traffic flows by content.

At the moment, documentation for solving actual operational tasks is under development, it will be further tested in urban bodies and enterprises.

\section{References}

1. A.A. Testeshev, V.D. Timohovetz, AIP Conference Proceedings, 1800, 050006 (2017)

2. V.V. Silyanov, Teorija transportnyh potokov $v$ proektirovanii dorog $i$ organizacii dvizhenija [Theory of traffic flows in the design of roads and traffic organization] (Transport, Moscow, 1979) (in Russian)

3. M. Treiber, A. Kesting, Traffic Flow Dynamics (Springer, 2013)

4. Yu.V. Trofimenko, M.R. Yakimov, Transportnoe planirovanie: formirovanie effektivnyh transportnyh system krupnyh gorodov [Transport planning: establishment of efficient transport systems of big cities] (Lotos, Moscow, 2013) (in Russian) 
5. A.E. Gorev, K. Bettger, A.V. Prokhorov, R.R. Gizatullin, Transportnoe modelirovanie [Transport Simulation], $1^{\text {st }}$ ed. (SPSUACE, St. Petersburg, 2015) (in Russian)

6. Y.V. Khomyak, Organizacija dorozhnogo dvizhenija [Organization of road traffic] (Vysshaja shkola, Kiev,1986) (in Russian)

7. V. Markuc, Transportnye potoki avtomobil'nyh dorog i gorodskih ulic [Transport flows of highways and the city streets], 48 (Tyumen, 2008) (in Russian)

8. V.M. Starozhilets, Yu.V. Chekhovich, Journal of Machine Learning and Data Analysis, 2(3) (2016) (in Russian)

9. A.A. Testeshev, V.D. Timohovetz, Transportation Research Procedia, 20, 643-648 (2017)

10. ODM 218.4.005-2010. Rekomendacii po obespecheniju bezopasnosti dvizhenija na avtomobil'nyh dorogah [Recommendations for road safety ensuring on roads] (Rosavtodor, Moscow, 2010) (in Russian)

11. H. Lieu, Traffic-Flow Theory. Public Roads, 62(4) (1999)

12. F. Heit, Matematicheskaja teorija transportnyh potokov [Mathematical theory of traffic-flows] (Mir, Moscow, 1966) (in Russian) 